\title{
Arctic oil and the eastern direction of Russia's energy policy
}

\author{
$A$ Kozmenko ${ }^{1, *}$ \\ ${ }^{1}$ Kola Science Center RAS, 184209, Fersman st., 146, Apatity, Russia
}

\begin{abstract}
The article describes the main features of Russia's position in the traditional and promising oil markets of Europe and China in the context of the importance of oil and gas income in the country's economy in the formation of the Federal budget of the Russian Federation. The resource base of the eastern direction of oil transportation "Polar region - Eastern Siberia - Pacific Ocean" is evaluated and the geo-economic feasibility of increasing oil supplies to China is justified. At the same time, the developed resource base the West Siberian oil and gas province will not be enough to ensure growing supplies in the east while maintaining the level of oil exports to Europe. Therefore, the task is to develop oil energy resources in the Arctic.
\end{abstract}

\section{Introduction}

The main features of Russia's energy policy have been systematically refined over the past 50-60 years. During this period, from the year of discovery (1965) and the beginning of operation (1969) of Russia's largest Samotlor oil field, with the production of so-called "light oil" the dependence of the Russian economy on oil and gas revenues was formed. The most intensive production at this field grew in the 70s - from 110 million tons. in 1976 to 158.9 million tons. (this is the peak of annual production) in 1980. This is Siberian Light premium oil (API density 36.5; sulfur content is quite low $0.68-0.86$ ), that usually is part of the main oil (83.5\% from all exports) brand - Russian Urals brand.

Also an increase in the consumption of energy resources by leading European countries led to this. In the $80 \mathrm{~s}$, production averaged up to 110 million tons. per year, in 1990-2010 production decreased to an average of 22 million tons. in year. Nowadays, $75 \%$ of 3.5 billion tons of recoverable reserves have been developed; in 2018, production amounted to 19.3 million tons.

During this period oil and gas tools gradually became one more unique method to the traditional (military-political) methods of regulating international relations with Western (and also in Eastern, despite joining the Soviet bloc) Europe - oil and gas by the end of the XX century were so organically implemented into the daily life of Europeans that have become such an integral part of the national security of Europe that disruptions in the supply of energy resources could lead to both economic and social collisions.

The first pipelines (Druzhba and Soyuz) and then the entire system of oil and gas transportation to Europe were created not only as economic objects, but also as confirmation of the geopolitical presence of the USSR and then Russia in this region, what brought the relaxation of international tensions in the era of the Cold War.

In addition, such a significance of energy resources for European consumers guarantees the flawless fulfillment of contractual obligations, that means the planned inflow of foreign exchange funds to the Federal budget of the Russian Federation.

In the structure of revenues of the Federal budget of Russia, oil and gas revenues averaged over the past six (2014-2019) years 42.6\% [1].

Russia holds a leading position in the world oil and oil products market. In 2019 more than 53\% of production was taken by the top five: USA - 746.7; Russia - 568.1; Saudi Arabia - 556.6; Canada - 274.9 and Iraq -234.6 million tons [2, P .sixteen]. It should be noted that the maximum production in the USSR (624 million tons) was reached in 1988, and in the USSR Russia itself - in 1983 (564.0 million tons), modern Russia reached that level only in 2018 with an oil production level of 563.3 million tons.

The same top five countries (2019) account more than $52 \%$ of oil exports (Saudi Arabia - 358.4; Russia 286.1; Iraq - 200.8; Canada - 197.0 and the USA - 137.7 million tons); $33 \%$ of petroleum product exports go to two countries - the USA and Russia - 251.1 and 164.6 million tons respectively. Russia also holds a leading position in the export of oil (over 29\%) and oil products (about 51\%) to Europe and ranks second after Saudi Arabia (83.3 million tons) in the export of raw oil to China (77.7 million tons or $15.3 \%$ of the total Chinese import) [2, P. 29].

Therefore, in the current context of overcoming the consequences of the pandemic and tightening antiRussian sanctions oil and oil products are still extremely important, if not the main instrument of the National Security Strategy of the Russian Federation [3] in the system of international relations and ensuring the 
implementation of this strategy in the energy sector "Energy strategy of the Russian Federation for the period up to 2035" approved in June 2020. [4]

\section{Eastern vector of Russia's energy policy}

Europe is traditionally the main consumer of Russian energy resources. In the structure of Russian exports (raw oil) Europe is in the lead - 56\%, followed by the Asia-Pacific countries - 33\%, including China - 26\% and Japan $-2.5 \%$ and the CIS countries - $7 \%$.

In the structure of Russian exports (petroleum products) Europe is also in the lead - 65\%, APR countries $-16 \%$, including Singapore $-6.1 \%$ and China $-1.3 \%$.

World oil consumption in the post-crisis period (since 2008) increased by $14 \%$ from 4150 to 4730 (2019) million tons. The increase in 2019 amounted to 0.924 million barrels per day or about 45 million tons of oil per year. The largest increase in oil consumption was demonstrated by the Asia-Pacific countries. In total, this figure was about $78 \%$ of the world, while China showed the largest increase in oil consumption in the world at the level of 33.2 million tons per year [2, p.21].

Oil consumption in Europe during this period fell by almost (million tons) $10 \%$. Oil consumption declined in almost all European countries, with the most significant declines in Italy (21.7), France (14.9), Spain (12.1) and Germany (10.5). Consumption increased only in Turkey, by $47 \%$, to the level of 48.6 million tons. [2, p.21]. Under these conditions, Russian exports remain at approximately the same level - over the past five years, there has been a decline in raw oil exports by 20-22 million tons per year and an increase in supplies of petroleum products by the same amount. At the same time, the main capacities of oil transportation to Europe remain unloaded; in 2018, the utilization of pipeline capacities (Druzhba oil pipeline) amounted - 73.5\% and port capacities - 67\% [5] (Table 1).

Table 1. Indicators of the oil transportation system to Europe (million tons)

\begin{tabular}{|l|c|c|}
\hline \multicolumn{1}{|c|}{ An object } & Bandwidth & $\begin{array}{c}\text { Transshipment } \\
(\mathbf{2 0 1 8} \text { })\end{array}$ \\
\hline $\begin{array}{l}\text { Druzhba } \\
\text { pipeline }\end{array}$ & 66,5 & 48,9 \\
\hline Primorsk port & 60,0 & 38,4 \\
\hline $\begin{array}{l}\text { Port of } \\
\text { Novorossiysk }\end{array}$ & 40,0 & 26,4 \\
\hline $\begin{array}{l}\text { Ust-Luga } \\
\text { port }\end{array}$ & 38,0 & 27,7 \\
\hline Total & $\mathbf{2 0 4 , 5}$ & $\mathbf{1 4 1 , 4}$ \\
\hline
\end{tabular}

This situation with the importance of oil exports for the Russian economy is a compelling reason to search for new directions for the export of energy resources, especially in the context of the rapid growth of consumption in China.

Also, since year 1974 some American restrictions have been constantly operating against our country - this is an element of the "cold war" by a the country unfriendly to Russia.

After the collapse of the USSR at the end of the 20th and the beginning of the $21 \mathrm{st}$ centuries, Russia's attempts to achieve an equal position with the leading Western countries were unsuccessful, as it was necessary to recognize the unconditional leadership of the United States, so as a result, Russia found itself outside the Euro-Atlantic system and turned into complete rival. They also failed to create their own center of power in Eurasia in the post-Soviet space, since the former Soviet republics do not want a return to the USSR and take national sovereignty as independence from Russia.

Since March 2014 after the increased sanctions Russia has lost cheap long-term loans from Europe and the United States, as well as high-tech American imports, including equipment for prospecting, exploration and production of oil and gas on the continental shelf. As a result, the American ExxonMobil withdrew from the strategic alliance with Rosneft to develop three Vostochno-Prinovozemelskiy license areas in the Kara Sea. In the first section, the worldfamous Universitetskaya-1 well was drilled and the Pobeda oil field was discovered within the Barents-Kara oil and gas province, - the increment of reserves amounted to 130 million tons of oil in quality like the premium Siberian Light and approximately 420 billion $\mathrm{m} 3$ of gas.

These sanctions are also extended to Nord Stream 2 (as a result, the Swiss-Dutch company Allseas Group, which accounted for more than $96 \%$ of the deep-water laying of the total length of the two pipelines), and the Power of Siberia-3 project for the development of the Kirinskoye gas condensate field on the continental shelf of Sakhalin.

There is a clear threat to the normal functioning of the Russian oil and gas transportation system to Europe. The Druzhba pipeline delivers oil to eight European NATO member states: Poland, Germany, Latvia and Lithuania (northern branch), Hungary, Slovakia, the Czech Republic and Croatia (southern branch), as well as Ukraine.

How these countries will behave when the sanctions on the Druzhba oil pipeline are extended - most likely, they will stop buying Russian oil.

So American sanctions are a reality, like an influenza epidemic or a coronavirus pandemic - it is difficult to fight it, but it is quite possible to learn to live with it.

A significant impetus in the development of oil supplies to the east was initiated with the commissioning of the first $(2694 \mathrm{~km}, 2009)$, and then the second stage (2046 km, 2012) of the Eastern Siberia - Pacific Ocean (ESPO) oil pipeline. Since November 2019, the oil pipeline has been brought to the maximum capacity of ESPO-1 "Taishet-Skovorodino" - 80 million tons / year, ESPO-2 "Skovorodino-Kozmino port" - 50 million tons / year. The capacity of the offtake is the border of the RF-PRC "Skovorodino - Mohe - Datsan" is 30 million tons in year. In 2019, 55.9 (out of 77) million tons were pumped to China via this pipeline oil, an additional 10 
million tons - via the pipeline State border of the Russian Federation - Kazakhstan - China and about 11 million tons by rail. The plan for 2020 is $57-60$ million tons.

The resource base of the ESPO pipeline is the fields located in the zone of the new pipelines Zapolyarye Purpe $(488 \mathrm{~km})$ and Vankor - Purpe $(556 \mathrm{~km})$, the oil from these fields further along the oil pipelines Purpe Samotlor (429 km), Samotlor - Aleksandrovskaya (23 $\mathrm{km})$, Aleksandrovskaya-Anzhero-Sudzhensk (818 km) and Anzhero-Sudzhensk-Taishet $(908 \mathrm{~km})$, through which oil is pumped to Taishet, oil is pumped there (Table 2) via the Kayumba-Taishet oil pipeline (703 $\mathrm{km}$ ). Thus, the total length of the oil pipeline along the Vankor-Mohe-Datsan oil transportation route is about $6,500 \mathrm{~km}$.

Tabl 2 Resource base of the eastern direction of oil transportation (million tons)

\begin{tabular}{|c|c|c|c|}
\hline Pipeline & Field & License & $\begin{array}{c}\text { Max } \\
\text { pumpi } \\
\text { ng in } \\
\text { year } \\
2020\end{array}$ \\
\hline \multirow[t]{13}{*}{$\begin{array}{l}\text { Zapolyar } \\
\text { ye-Purpe }\end{array}$} & $\begin{array}{l}\text { Vostochno- } \\
\text { Massoyakhin } \\
\text { skoe }\end{array}$ & Slavneft & 10,9 \\
\hline & $\begin{array}{l}\text { West } \\
\text { Massoyakhin } \\
\text { skoe }\end{array}$ & Slavneft & 2,4 \\
\hline & Russian & THK-BP & 6,8 \\
\hline & Zapolyarnoye & Gazprom & 2,3 \\
\hline & Tazovskoe & Gazprom & 1,0 \\
\hline & $\begin{array}{l}\text { North- } \\
\text { Urengoyskoe }\end{array}$ & Gazprom & 0,1 \\
\hline & Solekaptskoe & Lukoil & 0,3 \\
\hline & Urengoyskoe & Gazprom & 7,4 \\
\hline & Arctic fox & Gazprom & 0,1 \\
\hline & $\begin{array}{l}\text { En- } \\
\text { Yakhinskoe }\end{array}$ & Gazprom & 0,1 \\
\hline & Sambursk & $\begin{array}{l}\text { SeverEner } \\
\text { gia }\end{array}$ & 0,2 \\
\hline & $\begin{array}{l}\text { Yaro- } \\
\text { Yakhinskoe }\end{array}$ & $\begin{array}{l}\text { SeverEner } \\
\text { gia }\end{array}$ & 0,5 \\
\hline & $\begin{array}{l}\text { В.Уренгойск } \\
\text { ий лиц.уч-к }\end{array}$ & ТНК-BP & 1,1 \\
\hline \multicolumn{3}{|l|}{ TOTAL: } & 34,2 \\
\hline \multirow[t]{5}{*}{$\begin{array}{l}\text { Vankor - } \\
\text { Purpe }\end{array}$} & Vankor & Rosneft & 25,2 \\
\hline & Suzunskoe & ТНК-ВP & 4,0 \\
\hline & $\begin{array}{l}\text { Nakhodkinsk } \\
\text { oe, } \\
\text { Perekatnoe, } \\
\text { Pyakyakinsko } \\
\text { e }\end{array}$ & Lukoil & 0,4 \\
\hline & Tagulskoe & THK-BP & 4,6 \\
\hline & $\begin{array}{l}\text { Russko- } \\
\text { Rachenskoe }\end{array}$ & THK-BP & 0,7 \\
\hline
\end{tabular}

\begin{tabular}{|c|c|c|c|}
\hline & $\begin{array}{l}\text { Fakhirovskoe } \\
\text { Ust- } \\
\text { Chaselskoe, } \\
\text { Verkhne- } \\
\text { Chaselskoe, } \\
\text { Kynskoe, } \\
\text { Novo- } \\
\text { Chaselskoe }\end{array}$ & Rosneft & 0,4 \\
\hline \multicolumn{4}{|c|}{$\begin{array}{c}\text { TOTAL: } \\
35,3\end{array}$} \\
\hline \multicolumn{4}{|c|}{$\begin{array}{c}\text { TOTAL: (.) Purpe } \\
69,5 \\
\end{array}$} \\
\hline $\begin{array}{l}\text { Purpe - } \\
\text { Taishet }\end{array}$ & & & 69,5 \\
\hline \multirow[t]{2}{*}{$\begin{array}{l}\text { Kuyumb } \\
\text { a-Taishet }\end{array}$} & $\begin{array}{l}\text { Kuyumbinsk } \\
\text { oe }\end{array}$ & Slavneft & 0,8 \\
\hline & $\begin{array}{l}\text { Yurubcheno- } \\
\text { Tokhomskoe }\end{array}$ & Rosneft & 5,0 \\
\hline TOTAL: & & & 5,8 \\
\hline $\begin{array}{l}\text { TOTAL: } \\
\text { (.)Taishe } \\
\mathrm{t}\end{array}$ & & & 75,3 \\
\hline
\end{tabular}

*The draft program for the integrated development of the Yamalo-Nenets Autonomous Region and the north of the Krasnoyarsk region, "Vedomosti"

The largest of the fields in the eastern direction of oil transportation is the Vankor oil and gas field with a maximum pumping rate in 2020 of 25.2 million tons. Oil from one of the reservoirs (Nizhnekhetsky) of the Vankor oil and gas field (density 40 API, sulfur content $0.1 \%$ ) qualitatively exceeds the Brent Blend (Europe) and Dubai crude (APR), as well as Russian Urals. The weighted average oil indices of the Vankor oil and gas field are 30 API by density with a sulfur content of $0.2 \%$.

In addition, the ESPO resource base also includes fields located in the zone of the ESPO-1 oil pipeline, these are Verkhnechonskoye oil (Irkutsk region) and Talakanskoye oil and gas fields (Republic of Yakutia (Sakha).

The rapid development of production at the three largest fields in Eastern Siberia in the post-crisis period (since 2008) was ensured by the launch of the ESPO project, - the total production of three fields over ten years increased 40 times from the level of 1.4 million tons in 2008; in 2018 production amounted to 24.4 million tons at Vankor, 18.3 million tons at Verkhnechonskoye and 12.3 million tons at Talakan deposits [6, P.9-11]. During this period, production reached the maximum permissible level due to the significant depletion of these fields. The development of the Vankor field is over $75 \%$.

Further development of the eastern direction of diversification of oil transport communications is quite logically associated with the increase in oil supplies to China to the level of 100 million tons per year and further 150 (2029) and 200-210 million tons per year within the existing planning strategy of the Energy Strategy of the Russian Federation for the period up to 2035. 
By 2019, the level of raw oil consumption in China at the level of about 700 million tons (191 million tons own production and 507 million tons - imports) shows a significant (by 70\%) increase in this indicator over the past ten years and the economic potential to develop China's energy potential in the future.

Russia supplied 77.7 million tons of raw oil to China (2019) (and an insignificant amount of 3.1 million tons - $4 \%$ of total imports of the oil products), which is $15.3 \%$ of total Chinese imports. The leader is Saudi Arabia 83.3 million tons or $16.4 \%$ of Chinese imports. In total, raw oil exports to China from the Gulf countries in 2019 amounted to 206.3 (41\%), including [2, p.30] Saudi Arabia (83.3 million tons), Iraq (51.8 million tons). This is more than 2.6 times higher than the Russian export. Consequently, there is a field for competition for Russian oil ESPO in the oil market of China, access to which is provided by the developing communications system of the eastern direction.

It should be emphasized that an increase in export volumes to China will cause difficulties in ensuring oil exports to Europe at the current level, since the developed reserves of the main production region, West Siberian oil and gas production will not be enough to fill Urals mixtures (supplies to Europe) and ESPO (supplies to China) with the West Siberian light oil Siberian Light. In addition, the available capacities of the ESPO pipeline and the port of Kozmino are not enough to implement such a program.

This presupposes the development of the resource base for oil production in the Arctic, as well as the development of the Arctic communications system for oil transportation in the eastern direction.

Russia has clear geopolitical and logistical advantages. Since China is the world's leading oil importer (about 507 million tons per year) and oil products (more than 78 million tons per year), the main problem for China is the safety of transport flows for the delivery of these goods to China. This applies especially to the strategic Straits of Hormuz and Malacca (Singapore), i.e. zones that can be relatively easily blocked by the forces of international terrorism and are within the reach of US sanctions.

This is especially true of the Singapore Strait, which is only $4.6 \mathrm{~km}$ wide at its narrowest point. Covering the Malacca (minimum width $40 \mathrm{~km}$ ), Hormuz $(56 \mathrm{~km})$ or Bering $(86 \mathrm{~km})$ straits are much more difficult. Nevertheless, in the threat of the use of unjustified sanctions by the United States in these areas, it is necessary to organize escort of transports by the Navy of the states concerned.

It should be emphasized that the geographic location of the Eastern Siberia - Pacific Ocean oil pipeline excludes these risks and provides a clear logistic advantage - a shorter transport leg, which affects the oil price.

Secondly, the oil mixture supplied through the ESPO pipeline is named after this pipeline - "Siberia - East Pacific Ocean" -ESPO is a mixture of West Siberian premium oil Siberian Light, oil from the fields indicated in Table 2, as well as oil from fields located in the ESPO-1 zone. This blend is premium and has a qualitative advantage over the reference oil grade for the Asia-Pacific countries - Dubai crude. For example, one of the ESPO blends outperforms the reference Dubai crude in terms of density (34.8 and 31 API degrees) and sulfur content (0.53-0.62 and 2\%), therefore it trades at a premium of about USD 3.5-4 , 5 / bbl. to this marker variety.

In general, lighter (higher API) and less sulphurous crude with all other things being equal, trades more expensive (with a premium) due to lower costs for sulfur removal and refining. So the ESPO Blend mixture from these positions is more attractive than the Urals brand oil supplied from Russia to Europe (the oil mixture of the Druzhba oil pipelines of the Baltic Pipeline System, consisting of heavy high-sulfur oil from the Volga region and the Urals, density 26-28 degrees API, content sulfur - up to 3\% and West Siberian oil Siberian Light, density 36.5 degrees API, sulfur content $-0.57 \%$; this mixture has a resulting density of 31-32 degrees API and sulfur content $-1.2 \%$ ), but is inferior to the reference for Europe marker grade Brend Blend North Sea with a density of 38.3 degrees API and a sulfur content of $0.57 \%$.

The growth of oil imports in China is ensured by the demand for oil from independent refiners, the so-called "samovars" and the Chinese government allows direct oil imports to some (already more than ten) of these refineries.

\section{Spatial organization of sea communications and the Arctic oil transportation system}

Building up the export potential of oil to China and South Korea to 100-150 million tons. and more inevitably will face a shortage of production capacity, especially within the West Siberian oil and gas province .. In addition, the oil transportation system in the eastern direction needs modernization and expansion, the ESPO strengthening by building additional oil pipelines or organizing oil transportation along the Northern Sea Route (Polar Silk paths) in an easterly direction.

It should be emphasized that the non-Arctic states, incl. India, China, South Korea, Brazil, Japan and the EC countries tend to view the Arctic Ocean as a zone of interethnic interests, while Russia and Canada intend to retain national jurisdiction over both sea routes. [7] and the entire Arctic space. Under these conditions, interest in the role of Russia in the development of the Arctic, and in particular the prospects for the development of oil production, is quite large [8], and the development of the Russian Arctic can become the basis for long-term international cooperation, the development of integration mechanisms of interaction between companies, and help to increase the country's competitiveness [9].

In July 2020, Rosneft independently continued work on the Vostochno-Prinovozemelskiy license areas 1 and 2 in the Kara Sea. This time, the work is being carried out without the participation of foreign partners who withdrew from the strategic alliance with Rosneft due to 
pressure from the US sanctions of March 2014 - this is the already mentioned ExxonMobil company and North Atlantic Drilling, which withdrew from the alliance along with its Norwegian semi-submersible oil drilling platform SS Alfa West, which drilled the well "Universitetskaya-1".

NK Rosneft is drilling prospecting and appraisal Vikulovskaya (area 1) and Rogozinskaya (area 2) wells, the total reserves of which are about 2 billion tons. oil and 3.7 trillion. $\mathrm{m} 3$ of gas.

According to [10] drilling at the Vikulovskaya structure is carried out by the Chinese platform Nan Hai Jiu Hao (Nan Hai 9), which is owned by China Oilfield Services Limited, controlled by the state-owned China National Offshore Oil Corporation -CNOOC, China, Beijing.

In addition [10], two more Chinese platforms are operating in the Kara Sea - the semi-submersible Nanhai Bao Hao (Nan Hai 8) is drilling exploratory well No. 5 at the Leningradskoye gas condensate field commissioned by Gazprom, and the self-elevating Oriental Discovery is drilling the Ragozinskaya prospecting and appraisal well. At the same time (Rosnedra estimate) prepared resources of category Do of Vikulovskaya well amount to 700 billion m3 of gas and 300 million tons. oil, and Rogozinskaya - 1.2 trillion $\mathrm{m} 3$ of gas and 600 million tons. oil.

Thus, oil production in the fields of the continental shelf of the Kara Sea is a significant source of replenishment of the resource base.

In 2020, Rosneft will launch the Vostok Oil project with a completion period (start of operation) and a production level of 26 million tons. oil by 2024 . The project will require investments of about 10 trillion. rubles, USD 157 billion according to The Nikkei Asian Review.

The project includes oil, oil and gas and oil and gas condensate fields of the Vankor and Payakhinsky clusters, as well as the West Irinsky license area.

The total resource potential of the project is more than 5 billion tons. light, low-sulfur $(0.02 \%$ sulfur $)$ crude oil, premium relative to the Brent benchmark.

Rosneft plans to increase production to 50 million tons. by 2027 and up to 115 million tons. by 2030, which will require a significant modernization of the Arctic system of sea communications and, in particular, the Northern Sea Route. A certain part of the oil will be transported by domestic-built Arc7 reinforced ice-class shuttle tankers at the Zvezda Far East plant (Bolshoy Kamen).

Currently, three projects for the sea export of Arctic oil are being implemented - the Varandey project (PJSC Lukoil) and two projects of the Gazprom Neft Oil Company (the Arctic Gate and Prirazlomnaya). Under the Varandey project, Varandey mix oil is shipped through the Varandey (stationary sea ice-resistant offloading berth) Varandey (Barents Sea) and is delivered by shuttle tankers to the Kola storage tanker in the Kola Bay. The storage capacity is 12 million tons of oil per year. Under the OPEC + agreement, the shipment for this project will amount to no more than 7 million tons. oil per year [11, P.69].
A significant part of the oil in the "Varandey mixture" comes from the fields. R. Trebs and A. Titov and is trading at a discount of USD 2-3 per barrel relative to the reference Brent grade (density $825-828$ $\mathrm{kg} / \mathrm{m} 3,38.3 \mathrm{~g}$ API; sulfur content $-0.57 \%$ ). On average, the oil from the Timan-Pechersk oil and gas fields used in this project has a density of 0.826-0.885 $\mathrm{g}$ / cm3, 30-40 g API, low-sulfur (up to 1\%) and mediumsulfur (1-2\%), paraffinic (from 0.4 to $6.6 \%$ ).

Under the Arctic Gates project (Gulf of Ob, Kara Sea), Novy Port oil is delivered by shuttle tankers to the storage tanker Umba (Kola Bay) - the throughput capacity of the project in 2020 is about 8 million tons. By its properties, Novy Port oil belongs to the category of light (density at the level of Brent oil with a low sulfur content (about $0.1 \%$ ) and is traded on the world market with a premium to Brent oil of USD 3.0 per barrel.

Under the Prirazlomnaya project, ARCO heavy oil is delivered by shuttle tankers to the same storage tanker the throughput of this project in 2020 is a maximum of 6 million tons. Taking into account the OPEC + agreement, oil production for these two projects may amount to about 10 million tons. [11, P.69].

Export grade ARCO is the heaviest $(906 \mathrm{~kg} / \mathrm{m} 3 ; 24$ API) and sour (2.3\%) low paraffin oil among Russian export marker grades. The main export grade with a share of about $80 \%$ in the total volume is Urals (a mixture of heavy oils from the Volga region and Siberian Light) with a density of about $865 \mathrm{~kg} / \mathrm{m} 3$; API 31.5 degrees with a sulfur content of $1.2-1.3 \%$.

On the global market, ARCO is trading at a discount to Brent crude at USD 4-5 per barrel. ARCO is well suited for deep downstream processing in complex refineries in northwestern Europe.

Thus, the volume of sea exports of Arctic oil may amount to about 17 million tons per year.

In conclusion, the formation of new Arctic trade routes, it is necessary, first of all, to assess the impact of the expansion of sea communications on the habitat and functions of ecosystems [12], especially in coastal regions, taking into account the very likely accidents in the process of oil production and transportation in complex arctic conditions [13].

\section{Acknowledgment}

work was carried out within the framework of the research project No. 0226-2019-0022 IEP "Scientific and applied foundations of sustainable development and modernization of marine economic activities in the western part of the Arctic zone of the Russian Federation" on the state order of the Federal Research Center of the KSC RAS

\section{References}

1. Ministry of Finance of the Russian Federation. Federal budget. Available online: https: //www.minfin.ru/ru/statistics/fedbud/ (2020)

2. BP Statistical Review of World Energy 2020. 69th edition, 62 (2020) 
3. Strategy of National Security of the Russian Federation. Decree of the President of the Russian Federation "On the National Security Strategy of the Russian Federation." December 31, 683 (2015)

4. Energy strategy of the Russian Federation for the period up to 2035. Order of the Government of the Russian Federation "On approval of the Energy strategy of the Russian Federation for the period up to 2035", No.-1523-r (2020)

5. The capacity of the Druzhba export pipeline has been reduced by a third, Vedomosti Available online: https://www.vedomosti.ru/business/articles/2019/05 /05/800733-moschnost-nefteprovoda-druzhba (2020)

6. I. V. Filimonova, L. V. Eder, V. Yu. Nemov, I. V. Provornaya, Forecast of oil production in the regions of Eastern Siberia and the Republic of Sakha (Yakutia) 1, Drilling and oil 07-08, 9-19 (2019)

7. M. Blunden, Geopolitics and the northern sea route, International affairs 88(1), 115-129 (2012).

8. I. Overland, Russia's Arctic energy policy, International Journal 65(4), 865-878 (2010)

9. B. Baker, Law, Science, and the Continental Shelf: the Russian Federation and the promise of Arctic cooperation, Am. U. Int'l L. Rev. 25, 251 (2010)

10. .Kommersant, August 30, 2020, 156, 1 (2020)

11.S. Yu. Kozmenko, Regional factors of economic development of sea communications in the Arctic, Marine collection 6, 66-70 (2020)

12. A. W. Miller, G. M. Ruiz, Arctic shipping and marine invaders, Nature Climate Change 4(6), 413 (2014)

13. M. Knol, P. Arbo, Oil spill response in the Arctic: Norwegian experiences and future perspectives. Marine Policy 50, 171-177 (2014) 